Muñoz-Niklitschek Esteban, Morales-Delgado Paulo, Muñoz-Oyarzo Emilio, Parra-Venegas Rogelio. Opinion of medical students compared with non-medical students about organ donation and its bioethical conflicts. Journal of Education, Health and Sport. 2021;11(01):105-116. eISSN 2391-8306. DOI http://dx.doi.org/10.12775/JEHS.2021.11.01.011 https://apcz.umk.pl/czasopisma/index.php/JEHS/article/view/JEHS.2021.11.01.011 https://zenodo.org/record/4460148

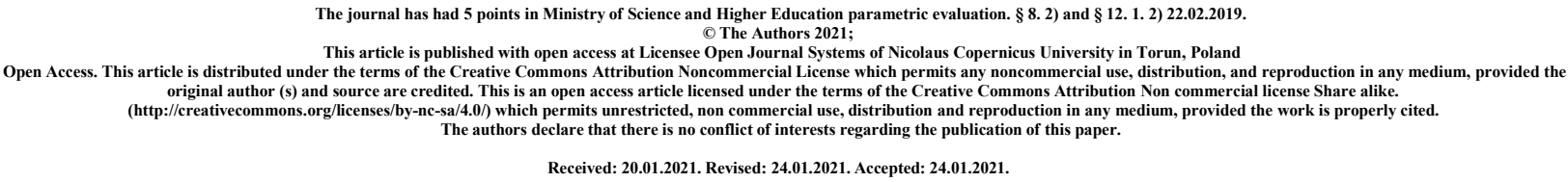

\title{
Opinion of medical students compared with non-medical students about organ donation and its bioethical conflicts
}

\section{Esteban Muñoz-Niklitschek ${ }^{1 *}$, Paulo Morales-Delgado ${ }^{1}$, Emilio Muñoz-Oyarzo ${ }^{1}$, Rogelio Parra-Venegas ${ }^{1}$}

${ }^{1}$ Faculty of Medicine, University of Concepción, Concepción, Chile

\author{
*Corresponding author: \\ Esteban Muñoz-Niklitschek \\ Av. Inglesa 350 \\ 4040409 Concepción, Chile \\ Tel. +56977049147 \\ e-mail: estemunoz@gmail.com
}

\begin{abstract}
Introduction and Purpose: Organ donation is controversial. Chilean legislation failed to increase donors. However, it seems that there is an enthusiasm to be an organ donor, so education is important. Therefore, medical students play an important role in educating, but the other students may not know these topics. Thus, the following work pretends to compare the opinions of medical students and non-medical students at the University of Concepción (UDEC) about organ donation and associated bioethical conflicts.

Material and Method: Observational, descriptive, cross-sectional study with qualitative and quantitative variables. It was used a 16-question survey, applied in Argentina, adapted to the Chilean culture. The sample was 60 students: 30 medical students and 30 students from other fields, outside the health area. Microsoft Windows Excel program was used to process the data.

Results: Mostly men were surveyed, on average 21.5 years. Engineering was more frequent after medicine, and mode was 4 years studied. The absence of belief predominated. In both groups the donation was considered good; that they would donate, because it is a way of giving a life; and what they would like to receive. In medicine they considered that those who donate are brave people, where the other group considered that they give their lives and are brave. Regarding the
\end{abstract}


concepts of brain death and Chilean law number 20.413, knowledge was lower in the nonmedical group.

Conclusions: We observe that medical university students handle some concepts related to donation in more detail than those who pursue careers outside the health area. Organ donation it is an issue that needs to be brought to discussion that should include the government authorities, local authorities, and the community.

Key words: Tissue and Organ Procurement, Bioethics, Bioethical Issues, Tissue Donors.

\section{Introduction:}

The Organ donation is an altruistic act that has helped to resolve various diseases that if it were not for the transplantation, it would end up killing the person. Of major, the procedure of extracting the organs and transplanting them has not been without controversy, due to the problem to define the death of the patient and the impact that this generates on family members, the adoption of the idea of being a donor is not homogeneous. On the other hand, transplants have 2 main modalities according to the type of donor: deceased donors and living donors. ${ }^{(1-3)}$

In deceased donors, it is necessary to define their death, which has become complicated because it is an irreversible event with a cultural impact. Nowadays, it is shown that the procurement and transplantation of organs is related to the cultural changes of a country, Spain being one of the countries with the highest rate of procurement and transplantation. In Chile, the law is the one that regulates the field of donations, in law number 20.413, which is a modification of law number 19.415. In this way, it goes from a system of "Required response" to one of "Presumed consent", to increase the numbers of donors, however it has not had the desired results, so it is urgent to achieve this Spanish achievement. ${ }^{(1-4)}$

Already in 1968, a commission was formed to define death, where the concept of brain death was born, which is the result of a cerebral circulatory arrest that leads to the total and irreversible loss of brain stem function. Therefore, by certifying the brain death of a patient, it is possible to remove their organs for donation without moral charges of accelerating death. In Chile, the diagnosis of brain death is clinical, which must be made by 2 doctors, at least one of them, a neurologist or neurosurgeon, who must not be linked to the transplant team and there should be no pressure from this team. The diagnostic criteria according to Chilean legislation (Law Num. $19,451)$ must be at least the following conditions: No voluntary movement observed for one hour; Apnea after three minutes of ventilator disconnection, and absence of brainstem reflexes. (2) (4 - 6)

Moreover, the transplant procedure must be carried out considering the 4 principles of bioethics: Autonomy, Justice, Beneficence and Non-maleficence. ${ }^{(1)}$

The Autonomy points out that the person through an altruistic act decides to give their consent to donate their organs, which can be stipulated by means of a will, a registration to a list of donors or by presumed consent by the law. However, despite these guidelines, it is possible that doctors 
hesitate to extract organs without the consent of the family, for fear of legal proceedings and for a moral obligation to comply with the family members, which is a point of conflict. ${ }^{(1)}$ (3)

Justice focuses on the fact that by defining death under the concept of brain death, it brings with it a great family and social repercussion, which generates discussion so that each person individually decides what to do with their organs in case of being in brain death. Another way to visualize it is by considering it a social act that links two subjects, on the one hand a donor and a receiver, where society fights with its generosity. Then, to carry out said act means the delivery of an organ to society, represented by the institution and not individually, (except in the case of a living donor), being an act of solidarity and moral commitment. Thus, by having a profound impact on society, it generates another source of conflict. ${ }^{(1)}(7)$

Nonmaleficence is related to not treating patients as means but as ends, so the diagnosis of brain death must be accurate and independent of eventual organ donation. In addition to maintaining the potential donor once brain death has been declared in order not to lose their organs and to carry out the transplant and improve the quality of life of the receivers. ${ }^{(1)(3)}$

Charity focuses on the fact that it is necessary to educate society so that it understands the situation of brain death and results in a collective benefit for all of us who in one way or another could occupy said benefit, for the very fact that it is necessary to change visions It is to be expected that reluctance will be generated towards organ donation. ${ }^{(1)}$

For example, considering the health service of Concepción, there were 3 effective donors, compared to the 13 of Viña del Mar and Quillota services, furthermore it lags the other health services in the region. Although according to a study in the Biobío region, almost eight out of ten people over 18 years of age are willing to donate their organs after death; $76 \%$ declared that they had talked with their family about organ donation and $40 \%$ had discussed with their loved ones the possibility of being a recipient if they needed it. Likewise, it is stated that among those who demonstrated against donating $(18 \%)$, the reasons put forward were that their health did not allow them (23\%); their religion does not allow them (18\%); they do not trust the system (13\%); a fear of accelerating clinical death (12\%) and some do not like the idea of intervening the body (12\%), among other reasons. According to this survey, $24 \%$ have not talked about the possibility of donating and $60 \%$ have not talked about the possibility of being a recipient if they need it. $63 \%$ of those surveyed stated that, faced with the possibility of donating organs, they want their family to be consulted and $35 \%$ prefer that their wishes be respected without asking the family. ${ }^{(8)}$

\section{Purpose:}

Although there is an apparent enthusiasm for being a donor, it is not conditioned by the current state of the number of effective donors, and it is also not negligible that in this small group of $18 \%$ little founded ideas are wielded such as "fear of accelerating clinical death ", which could influence the number of donor cases, so education plays an important role in achieving a more altruistic society, where medical students play an important role, but the rest of the students could lack of instruction regarding topics, so there is a knowledge gap regarding the degree of knowledge of organ donation and its conflicts, therefore the present study seeks to compare the opinions of medical students and non-medical students from the University of Concepción about organ donation and associated bioethical conflicts. ${ }^{(9)}$

\section{Material and Methods:}


An Observational, descriptive, cross-sectional study that considered medical students (Group 1) and other students outside the health area (Group 2) of the University of Concepción (UDEC). For each group there was a sample of 30 students, being 60 in total. Qualitative and quantitative variables were used.

The inclusion criteria were: Any undergraduate student of the medical major or other major outside the health area of the UDEC, who was studying the academic year 2017 at the time of the survey. The exclusion criteria were: Any student who belonged to other majors in the health area, which consisted of: Nutrition, Kinesiology, Nursing, Dentistry, Speech Therapy and, Obstetrics and Childcare; or that he was not studying the academic year 2017 and / or belonged to a postgraduate study plan.

For the data collection, a survey applied in Argentina was used in the study: "Opinion survey on organ donation and transplantation" (Ojeda, Jorge A. et al.) ${ }^{(10)}$, Which had 16 questions in total, of which they were discarded two questions for not corresponding to any of the specific objectives, one question was discarded due to a misunderstand when the survey was tested with the $10 \%(n=6)$ of the sample, then three questions were incorporated, the first was: "What major are you studying?" to better visualize the sample; plus the second and third which were: "If you answered" Yes "in the previous question, answer: What organs can be donated?", and "If you answered" Yes "in the previous question, answer: How do you know that you can decide? (Check one)", since they were within another section in the original survey, thus seeking better understanding. At the end, there were 16 questions left. In addition, the term "Occupation" was modified by the word "Major", and the phrase "Law of the presumed donor" by "Law 20.413: Being a donor by law." Of the questions: The first four referred to determine sociodemographic characteristics between the two groups based on sex, age, and religion. The next five referred to compare the decision-making of the two groups regarding organ donation, and the last five referred to compare the knowledge of the two groups regarding concepts related to bioethical conflicts. They were selection, open-ended and completion questions.

The survey (Figure $\mathrm{N}^{\circ} 1$ and Figure $\mathrm{N}^{\circ}$ ) was prepared in an online format using the "Google forms" program, accompanied by an informed consent prior to the survey, which indicated that it was anonymous, voluntary, with the possibility of retracting at any time and that the data only it would be used for this paper. After that, the survey was published in the online sections of the social platform "Facebook" referring to student centers, major groups, or other associations, used by the target individuals. The survey was kept available for completion until the exact number of samples was covered.

After that, the Microsoft Windows Excel program was used to tabulate data and statistical calculations were performed for each variable; using mode for the thirteen of the questions and mean and range for the age variable. 
Figure $\mathrm{N}^{\circ} 1$ : The Survey about organ donation which was used for this study in English.

1.-Age:

2.-Sex: Male Female

Other:

3.- What career are you studying? Medicine

Other:

4.- What year are you attending? $1-2-3-4-5-6-7$

5.- Do you consider yourself a follower or do you practice any religion? Which?

6.- What do you think of organ donation? (Mark one)

It is a good thing There are more important things I do not want to express an opinion

I never considered it Other:

7.- Do you agree to donate your organs? YES

No I do not know

Answer ONE of the following questions depending on the previous answer.

7a.- Yes, because... (Mark one option)

For solidarity ___ For love Because it is a way of giving life

Because I think it is alright Other:

7b.- No, because... (Mark one option)

Because I am scared By religion Fear of organ trafficking

Fear of the mutilation of the body Fear that death will accelerate

Other:

7c.- I do not know, because... (Mark one option)

I lack information Never thought about it I do not want to die Other:

8.- If your life depended on an organ, would you like to receive it through a donation? Yes No

9.- Do you know the organs and tissues that can be donated? Yes No

10.- If you answered in the previous question "Yes", answer: Which organs can be donated?

11.- Have you ever heard of brain death? Yes No

12.- Have you heard about Law 20,413, "Being a donor by law"? Yes

13.- Do you know someone who is currently waiting for an organ? Yes No

14.- Did you know that you can decide on your organs in life? Yes No

15.- If you answered "Yes" to the previous question, answer: How do you know you can decide? (Mark one) Because I heard it in the media Because we talked about it in family

Because I know people who donate organs ___ Because I heard it in the faculties

Other:

16.- What is your opinion of people who donate their organs? (Mark one)

It seems to me that they give away their life They are very brave

That they risk the doctors not trying so hard to save them

Other: 
Figure $\mathrm{N}^{\circ} 2$ : The Survey about organ donation which was used for this study in Spanish.

1.-Edad:

2.-Sexo: Hombre___ Mujer___ Otro:

3.- ¿Qué carrera estudia? Medicina__ Otro:

4.- ¿Qué año cursa? $1 \_2-3 \_4-5-6 \_7 \_$

5.- ¿Se considera adepto o practica alguna religión? ¿Cuál?

6.- ¿Qué opina usted de la donación de órganos? (Marque una opción)

Es algo bueno

Hay cosas más importantes

No quiero emitir opinión al respecto

Es algo que nunca me planteé___ Otro:

7.- ¿Está usted de acuerdo de donar sus órganos? Sí ___ No__ No sé ___

Responda UNA de las siguientes preguntas dependiendo de la respuesta anterior.

7a.- Sí, porque... (Marque una opción)

Por Solidaridad___ Por Amor___ Porque es una forma de dar vida_

Porque creo que está bien___ Otro:

7b.- No, porque... (Marque una opción)

Porque tengo miedo___ Por la religión___ Por miedo al tráfico de órganos

Por miedo a la mutilación del cuerpo___ Por miedo a que se acelere la muerte

Otro:

7c.- No sé, porque... (Marque una opción)

Me falta información___ Nunca lo pensé

No quiero morir

Otro:

8.- Si su vida dependiera de un órgano, ¿Le gustaría recibirlo a través de una donación? Sí

No

9.- ¿Conoce los órganos y tejidos que se pueden donar? Sí No

10.- Si respondió en la pregunta anterior "Sí", responda: ¿Qué órganos se pueden donar?

11.- ¿Escuchó hablar alguna vez sobre la muerte encefálica? Sí

No

12.- ¿Escuchó hablar de la Ley 20.413, "Ser donante por ley"? Sí

No

13.- ¿Conoce a alguien que en este momento está en espera de un órgano? Sí No

14.- ¿Sabía usted que puede decidir sobre sus órganos en vida? Sí__ No

15.- Si respondió en la pregunta anterior "Sí", responda: ¿Cómo sabe usted que puede decidir?

(Marque una opción)

Porque lo escuche en los medios de comunicación___ Porque lo hablamos en familia

Porque conozco gente que dono órganos__ Porque lo escuche en las facultades

Otro:

16.- ¿Qué opinión tiene de la gente que dona sus órganos? (Marque una opción)

Me parece que regalan su vida___ Son muy valientes

Que se arriesgan a que los médicos no se esfuercen tanto en salvarlos

Otro: 


\section{Results:}

About the results, we can describe that a total of 60 people were surveyed, of which $33 \%(n=20)$ were Men and $67 \%(\mathrm{n}=40)$ were Women. The average age was 21.5 years with a range of $18-27$ years.

Now, regarding the majors that the students belonged to, they are shown in Table $\mathrm{N}^{\circ} 1$, of this group the majority belonged to medicine with $50 \%(\mathrm{n}=30)$ and civil engineering with $25 \%(\mathrm{n}=$ $15)$.

Table $\mathrm{N}^{\mathrm{o}} 1$ : Frequency of university major of the students who answered the survey.

\begin{tabular}{lr}
\hline University Major & Frequency $(\mathrm{n} ; \%)$ \\
\hline Medicine & $30 ; 50 \%$ \\
Civil Engineering & $15 ; 25 \%$ \\
Bachelorship & $1 ; 2 \%$ \\
Psychology & $3 ; 5 \%$ \\
Journalism & $2 ; 3 \%$ \\
Architecture & $1 ; 2 \%$ \\
Agronomy & $1 ; 2 \%$ \\
Pedagogy in physical education & $1 ; 2 \%$ \\
Law & $2 ; 3 \%$ \\
Astronomy & $1 ; 2 \%$ \\
Visual Arts & $1 ; 2 \%$ \\
Marine biology & $1 ; 2 \%$ \\
Veterinary & $1 ; 2 \%$ \\
\hline Total & $60 ; 100 \%$
\end{tabular}

Considering the years of studies taken by those who responded to the survey, we obtained that they ranged from 1st year students to 6th year of their respective university majors and fashion was 4th year of university major. Most do not belong to any religious belief, being $53 \%(n=32)$, as shown in table $\mathrm{N}^{\mathrm{2}} 2$.

Table $\mathrm{N}^{\mathrm{o}} 2$ : Frequency of university religious beliefs of students who answered the survey

\begin{tabular}{lr}
\hline Religious belief & Frequency $(\mathrm{n} ; \%)$ \\
\hline None & $32 ; 53 \%$ \\
Catholic & $18 ; 30 \%$ \\
Christianity & $7 ; 11 \%$ \\
Buddhism & $1 ; 2 \%$ \\
Evangelical & $1 ; 2 \%$ \\
Orthodox & $1 ; 2 \%$ \\
\hline Total & $60 ; 100 \%$
\end{tabular}

Regarding the results of the question "What do you think about organ donation?", They are shown in table $\mathrm{N}^{\mathrm{o}} 3$. The responses between medical students and students of other majors were 
compared, showing that all medical students consider it to be a good thing, but in the other students, only $83 \%(n=25)$ consider it to be a good thing.

Table No3: Answers to the question "What do you think of organ donation?", Comparing the group of medical students and other university majors.

\begin{tabular}{lll}
\hline Opinion & Medical students (n; \%) & Other majors $(\mathrm{n} ; \%)$ \\
\hline It is a good thing & $30 ; 100 \%$ & $25 ; 83 \%$ \\
$\begin{array}{l}\text { I never considered it } \\
\text { I do not want to express an } \\
\text { opinion }\end{array}$ & $0 ; 0 \%$ & $2 ; 7 \%$ \\
$\begin{array}{l}\text { There are more important } \\
\text { things }\end{array}$ & $0 ; 0 \%$ & $1 ; 3 \%$ \\
\hline Total & $30 ; 100 \%$ & $2 ; 7 \%$ \\
\hline
\end{tabular}

Regarding the results of the question "Do you agree to donate your organs?" Comparing between the two groups, in the group of medical students there is a higher frequency of affirmative positive responses. The results are shown in Table $\mathrm{N}^{\mathrm{o}} 4$.

Table No4: Answers to the question "Do you agree to donate your organs?", Comparing the group of medical students and other university majors

\begin{tabular}{lll}
\hline Opinion & Medical students $(\mathrm{n} ; \%)$ & Other majors $(\mathrm{n} ; \%)$ \\
\hline Yes & $28 ; 93 \%$ & $23 ; 77 \%$ \\
No & $0 ; 0 \%$ & $3 ; 10 \%$ \\
I do not know & $2 ; 7 \%$ & $4 ; 13 \%$ \\
\hline Total & $30 ; 100 \%$ & $30 ; 100 \%$
\end{tabular}

Of those who answered "Yes", the following ratios were obtained from the two groups, indicated in table $\mathrm{N}^{0} 5$; where most of the medical students indicated that they did it because it is a way of giving life, at the same time the other students indicated the same reason, but less frequently.

Table No5: Affirmative Answers "Do you agree to donate your organs?", Comparing the reasons the group of medical students and other university majors

\begin{tabular}{|c|c|c|}
\hline Reason & Medical students (n; \%) & Other majors $(\mathrm{n} ; \%)$ \\
\hline Because it is alright & $6 ; 21 \%$ & $6 ; 26 \%$ \\
\hline $\begin{array}{l}\text { Because it is a way of giving } \\
\text { life }\end{array}$ & $16 ; 57 \%$ & $12 ; 52 \%$ \\
\hline $\begin{array}{l}\text { There is no point in keeping } \\
\text { the organs }\end{array}$ & $1 ; 3 \%$ & \\
\hline For love of neighbor & $1 ; 3 \%$ & $1 ; 5 \%$ \\
\hline For solidarity & $3 ; 11 \%$ & $4 ; 17 \%$ \\
\hline $\begin{array}{l}\text { Because it is an alternative to } \\
\text { therapy }\end{array}$ & $1 ; 3 \%$ & $0 ; 0 \%$ \\
\hline Total & $28 ; 100 \%$ & $23 ; 100 \%$ \\
\hline
\end{tabular}

Of those who answered "No", it was observed that in Medicine no one answered "No", on the other hand, other majors gave the following opinions expressed in table $\mathrm{N}^{\mathrm{o}} 6$. 
Table N6: Negative Responses "Do you agree to donate your organs?", From students at other university majors.

\begin{tabular}{ll}
\hline Reason & Frequency $(\mathrm{n} ; \%)$ \\
\hline Fear of organ trafficking & $1 ; 33 \%$ \\
Because I am scared & $1 ; 33 \%$ \\
Because consciousness persists in the body for a few days & $1 ; 33 \%$ \\
after death & $3 ; 100 \%$
\end{tabular}

Those who answered "I don't know" in question 7, expressed the following opinions among the groups; those of medicine expressed that they had never thought about it, on the other hand in the students of other majors they are shown in Table $\mathrm{N}^{0} 7$.

Table N7: Doubtful Responses "Do you agree to donate your organs?", From students at other university majors.

\begin{tabular}{ll}
\hline Reason & Frequency $(\mathrm{n} ; \%)$ \\
\hline I lack information & $1 ; 25 \%$ \\
For being a taboo & $1 ; 25 \%$ \\
Never thought about it & $2 ; 50 \%$ \\
\hline Total & $4 ; 100 \%$
\end{tabular}

In the question "If your life depended on an organ, would you like to receive it through a donation?", It was shown that all the medical students answered affirmatively, and in the case of the other students from other majors, only one would refuse to receive an organ.

Regarding the following question: "Do you know the organs and tissues that can be donated?", The medical students answered mostly in the affirmative, in turn, the students from other majors, the majority answered negatively. The results are displayed in Table $\mathrm{N}^{\circ} 8$.

Table No8: Answers to the question "Do you know the organs and tissues that can be donated?", Compared between groups.

\begin{tabular}{lll}
\hline Answer & Medical students $(\mathrm{n} ; \%)$ & Other majors $(\mathrm{n} ; \%)$ \\
\hline Yes & $23 ; 77 \%$ & $10 ; 33 \%$ \\
No & $7 ; 23 \%$ & $20 ; 67 \%$ \\
\hline Total & $30 ; 100 \%$ & $30 ; 100 \%$
\end{tabular}

Of the people who answered affirmatively to the question "Do you know the organs and tissues that can be donated?", They were asked to answer the following question, which organs can be donated? Both in the case of medicine and in the other students, the heart transplant stood out; the rest of the results are in Table $\mathrm{N}^{0} 9$.

Table N9: Answers to the question What organs can be donated?", Compared between groups.

Organs chosen by medical $\quad$ Frequency $\quad$ Organs chosen by other Frequency




\begin{tabular}{llll}
\hline students & (n) & students & (n) \\
\hline Heart & 20 & Heart & 10 \\
Liver & 21 & Liver & 9 \\
Kidney & 20 & Kidney & 7 \\
Lungs & 13 & Lungs & 3 \\
Cornea & 14 & Cornea & 3 \\
Bone & 5 & Others: Skin, marrow & 2 \\
Others: Skin and Marrow & 13 & Others: pancreas, & 2 \\
& & intestine and stomach & \\
Others: pancreas, intestine & 6 & & \\
Others: hair and face & 4 & &
\end{tabular}

About the question "Have you ever heard about brain death?", The medical students answered affirmatively, corresponding to $93 \%(\mathrm{n}=28)$, and in the case of the other students it was $57 \%(\mathrm{n}$ $=17)$.

The next question "Have you heard about Law 20,413," Being a donor by law? ", Again, the medical students answered affirmatively, corresponding to $73 \%(\mathrm{n}=22)$, and in the case of the other students, the majority responded negatively, corresponding to $57 \%(n=17)$.

Regarding the question "Do you know someone who is currently waiting for an organ?", The majority of both the group of medical students and other students answered negatively, corresponding to $77 \%(\mathrm{n}=23)$ and $87 \%(\mathrm{n}=26)$ respectively.

Regarding the question "Did you know that you can decide on your organs in life?", The majority in both groups answered affirmatively, being $100 \%$ in the medicine group $(\mathrm{n}=30)$ and $93 \%$ in the group of other students. \% $(\mathrm{n}=28)$. In the same way, those who responded affirmatively had been asked to indicate "How do you know that you can decide?", Obtaining the results in Table $\mathrm{N}^{\mathrm{o}} 10$.

Table $\mathrm{N}^{\circ} 10$ : Reasons for the affirmative answers to "Did you know that you can decide on your organs in life?", Compared between groups.

\begin{tabular}{|c|c|c|}
\hline Reason & Medical students (n; \%) & Other majors (n; \%) \\
\hline $\begin{array}{l}\text { Because I heard it in the } \\
\text { media }\end{array}$ & $12 ; 40 \%$ & $15 ; 53 \%$ \\
\hline $\begin{array}{l}\text { Because I heard it in the } \\
\text { faculties }\end{array}$ & $11 ; 36 \%$ & $3 ; 11 \%$ \\
\hline $\begin{array}{l}\text { Because we talked about it } \\
\text { in family }\end{array}$ & $3 ; 10 \%$ & $8 ; 29 \%$ \\
\hline Because I heard it in class & $2 ; 7 \%$ & $1 ; 4 \%$ \\
\hline Because I researched it & $2 ; 7 \%$ & $0 ; 0 \%$ \\
\hline $\begin{array}{l}\text { Because I know people who } \\
\text { donate organs }\end{array}$ & $0 ; 0 \%$ & $1 ; 3 \%$ \\
\hline Total & $30 ; 100 \%$ & $28 ; 100 \%$ \\
\hline
\end{tabular}

Finally regarding the question "What is your opinion of people who donate their organs?" , the following opinions of the different groups were collected, shown in table $\mathrm{N}^{\circ} 11$. 
Table $\mathrm{N}^{\mathrm{o}} 11$ : Responses to the question "What is your opinion of people who donate their organs?", Compared between groups.

\begin{tabular}{lll}
\hline Opinion & Medical students $(\mathrm{n} ; \%)$ & Other majors $(\mathrm{n} ; \%)$ \\
\hline They are very brave & $10 ; 34 \%$ & $15 ; 50 \%$ \\
They are supportive & $1 ; 4 \%$ & $2 ; 7 \%$ \\
$\begin{array}{l}\text { That they risk the doctors } \\
\text { not trying so hard to save }\end{array}$ & $0 ; 0 \%$ & $4 ; 14 \%$ \\
them & \\
$\begin{array}{l}\text { They give away their life } \\
\text { An excellent decision }\end{array}$ & $11 ; 37 \%$ & $3 ; 10 \%$ \\
$\begin{array}{l}\text { They give another person } \\
\text { the opportunity to live }\end{array}$ & $1 ; 3 \%$ & $1 ; 4 \%$ \\
$\begin{array}{l}\text { Respectable } \\
\text { It is the right thing }\end{array}$ & $1 ; 3 \%$ & $1 ; 4 \%$ \\
They are noble & $3 ; 10 \%$ & $1 ; 4 \%$ \\
\hline Total & $1 ; 4 \%$ & $3 ; 10 \%$ \\
\end{tabular}

\section{Discussion:}

It is important to highlight that most of the people who answered the survey, were young people. This is a fact to highlight for the purposes of the study, since we must consider that it is this young population who are the most exposed and open to a greater number of external opinions that can influence their decisions, such as in this case the Donation of Organs. Now in relation to the majors taken, it seems that the sample was representative of the university population. Because the main major at the university is engineering, so it was expected that this was one of the biggest groups. Another data to consider is the time that the students have spent at the university, those who have spent more time in the university, they can identify themselves with certain groups and positions, in relation to controversial issues such as "Organ Donation".

One of the key research questions is what they think about organ donation. Here $100 \%$ of the medical students consider it to be "Something good". Now when talking about the other majors we have a greater variety of responses, but those who considered it to be " It's a good thing " are still the vast majority, then followed more indifferent answers such as "I never considered it", "There are more important things". This gives us an indication of the opinions of those who are immersed in a health care environment. In comparison with other studies, one done in Mexico, it was found that medicine students got small information through college in relation with organ donation, but they willingness to donate was high, or two studies done in Poland, showed that medicine students agreed on procurement of organs. Also, in the paper of G Kobus. Et al. they compare medical and non-medical students' opinions about organ donation, with similar findings, where the medical ones embrace more frequently the idea of organ donation. ${ }^{(11-13)}$

Now when talking about "Donating your organs", the answers varied again, something to note is that in medicine 93\% answered that "yes I would" leaving a small percentage for "I don't know" showing a slight difference to the $100 \%$ trend about donating organs was something positive. In contrast, the preferences of the other majors were more varied, some replied "yes" $77 \%$, others replied "No" and "I do not know". Also, when a change of roles was made, where the situation was "If your life depended on an organ, would you like to receive it through a donation?", those 
who studied Medicine, all selected that "Yes, they would like", compared to those who studied other careers where most of them replied yes. The answer to this question indicates something curious, since almost all the subjects would like to receive an organ, while not everyone would be willing to donate their own. In comparison with other studies, the same trend is found, where the concept of donating an organ is embraced, but when the topic implies what the subject will do, the replies vary. Also, in the paper of M Rydzewska. Et al. they included the situation of what the student would do if it had to decide to regard the organ donation of a relative, with similar results. In one paper done by Paloma Peroni Contiero et al. where they explored the ambivalence toward organ donation, the students had this ambivalence of were more willing to receive an organ than to donate, and the reasons behind were related to their personal beliefs and moral codes, religion, level of knowledge, and the existence of ambivalence. (12) (14)

When referring to Knowledge of university students about which organs can be donated, the results were as expected, where medical students stated that they had a greater mastery of this topic. "Brain death" another important concept to understand what organ donation today, more than half of the respondents is referred to know this term, although the difference between the groups was somewhat overwhelming where in medicine and Other majors the percentages were 93\% and 57\% respectively, which makes it possible to consider again that knowledge of concepts has a lot to do with the formation of the major to which the respondents belong. This also took place when comparing the knowledge of Law number 20.413 "being a donor by law". About the question: if they knew that there is the possibility of deciding on their organs in life. Where the results were very affirmative by all the medical students who answered knowing this situation, instead who belong to other majors $93 \%$ stated they were aware of this and only $7 \%$ did not know it. When consulting from where the above information comes, for medical students the main source of this was from the "Media" with $40 \%$ closely followed by "Having heard it at the Faculty" 36\%. The same question in the other majors, the most information comes from the "Media" as well. In other studies, similar trends were found, for example in a Spanish paper, one of the main ways to know about the organ donation was by the media and relatives, which could influence in the decision making of the students. Also, in this Spanish paper and in the Mexican one, they highlighted that the students felt they had a lack of information about organ donation. (11) (15)

\section{Conclusions:}

We want to mention that organ donation is an altruistic act that has helped to solve various diseases that, if not for transplantation, end up killing the person and that it has become one of the most important issues in the health of Chile and the world, but which is not exempt from taboos as we could observe in the development of this survey. Although the results also showed that there is a high acceptance in this type of population "young university students" when it comes to donating organs and the majority see it with good will, which could shed light on a promising future.

We observe that medical university students handle some concepts related to donation in more detail than those who pursue careers outside the health area, this is a clear index of training throughout their careers and according to this lack of knowledge of terms, such as: "Brain death" and "Law 20.413" is that certain taboos and / or some misinformed opinions are generated on the subject. 
Organ transplantation is not without complications, but it is an issue that needs to be brought to discussion that should include the government authorities, local authorities, and the community. This topic should become a regular topic of conversation among people; thus, the numbers of donors and successful transplants increase; the taboos and unsupported reasons disappear.

\section{References:}

1. Carral, J., Parellada, J. et al. Bioethical issues for postmortem donation for organ transplants. Rev Cub Med Int Emerg. 2003; 2(2).

2. Contreras A. L. Organ Donation: Ethical Analysis of the Chilean Situation. Revista Medicina y Humanidades; 2011; 3:76-86.

3. Meléndez Minobis M, Dujarric Martínez M, Fariñas Rodríguez L, et al. Ethical implications of brain death and organ transplants. Rev Cubana Invest Bioméd. 2005; 24(1).

4. Law Num ${ }^{\circ}$ 19.451. National Congress Library, Chile. 2017.

5. Díaz V. Brain death or encephalic death. Death is one. Rev Hosp Clín Univ Chile. 2009; 20 : 263-70.

6. Hoppe A. Brain Death: clinical and legal considerations. Rev. Med. Clin. Condes. 2010; 21(2): 160-165. doi: 10.1016/S0716-8640(10)70520-4

7. Vélez, E. Organ donation - an anthropological perspective. Rev Soc Esp Enferm Nefrol. 2007; $10(3)$.

8. MINSAL. Organ donor and recipient data. Chilean Government. 2015.

9. Micheli C. Medical students and organ donation in Chile. University of development, Chile. 2010 .

10. Ojeda, Jorge A., Almada Carolina A., Fernández Vallejos, et al. An Opinion survey about organ donation and transplant. Scientific and technologic Reports. National University of Northeast, Argentina. 2006.

11. Sebastián-Ruiz MJ, Guerra-Sáenz EK, Vargas-Yamanaka AK, et al. Knowledge and attitude towards organ donation of medicine students of a Northwestern Mexico public university. Gac Med Mex. 2017;153(4):430-440. doi: 10.24875/GMM.17002573. PMID: 28991282.

12. Rydzewska M, Drobek NA, Małyszko ME, et al. Opinions and Attitudes of Medical Students About Organ Donation and Transplantation. Transplant Proc. 2018 Sep;50(7):1939-1945. doi: 10.1016/j.transproceed.2018.03.128.PMID: 30177084.

13. Kobus G, Reszec P, Malyszko JS, et al. Opinions and Attitudes of University Students Concerning Organ Transplantation. Transplant Proc. 2016 Jun;48(5):1360-4. doi: 10.1016/j.transproceed.2016.01.045. PMID: 27496405.

14. Contiero PP, Wilson DM. Understanding ambivalence toward organ donation and transplantation: An exploratory study of nursing students. Nurse Educ Today. 2019 May; 76:191195. doi: 10.1016/j.nedt.2019.02.008. PMID: 30822605.

15. Ríos A, López-Navas A, Gutiérrez PR, et al. Information About Donation and Organ Transplantation Among Spanish Medical Students. Transplant Proc. 2020 Mar;52(2):446-448. doi: 10.1016/j.transproceed.2019.11.041. PMID: 32057497. 